\title{
17 Chronicle of a backlash foretold
}

\author{
Guatemala's National Police \\ archives, lost and found and \\ lost - and found? - again ${ }^{1}$
}

\section{Kirsten Weld}

"Even ten years ago," the activist told me, "they would have killed all the people working on a project like that." It was 2008 , he was referring to the unlikely discovery and rescue of the archives of Guatemala's National Police three years earlier, and he was deadly serious. In 2005, a nighttime explosion on a Guatemala City military base had set in motion a shocking chain of events, culminating in the revelation that some 75 million pages worth of moldering police records, long and desperately sought by the families of the hundreds of thousands killed or disappeared by state security forces during the country's 36 years of armed conflict, had for years been hiding in plain sight in an urban storage depot. The political context at the time was inhospitable, to say the least. The war's root causes remained unaddressed, no army or police perpetrators had ever been prosecuted for their war crimes, and democracy activists were routinely threatened and harassed - or worse. Nevertheless, in the following years, a quixotic citizen effort to preserve and provide public access to this enormous corpus of files not only survived, but also thrived, making headlines around the world for its unlikely success in digitizing the archives and making them available for courtroom justice and historical research (Weld, 2014). Perhaps, as the activist suggested cautiously, things in Guatemala really had changed.

Or had they? A decade after our conversation, a full-spectrum assault on the country's tentative turn toward postwar reckoning had taken shape, and what had since come to be known as the Historical Archives of the National Police (AHPN) would sit squarely in the cross-hairs. Guatemalan conservatives, newly empowered by the presidencies of Jimmy Morales at home and Donald Trump further north, showed that they, like their counterparts elsewhere in Latin America, had made a strategic recalculation. To destroy dissenting political visions, they realized, no longer required assassinating all the dissenters. Instead, the law could be conscripted, and bent where necessary, to do the work, as seen in the so-called judicial coups undertaken in Honduras (2009), Paraguay (2012), and Brazil (2016). Dismantling the country's vaunted UN-backed Commission Against Impunity (CICIG), 
reversing hard-won anticorruption reforms in the judiciary, and effectively shuttering the National Police archives - all this could be done without firing a single bullet. It was thusly that the AHPN went from an improbable triumph to a tragedy foretold, a defeat cruelly snatched from the jaws of a victory that no one had quite been able to believe in the first place.

Guatemala's archive story has been unusually dramatic, but its core elements, above all the intensely political nature of access to state archives, are familiar to pro-democracy activists and archives managers the world over. Archive power is, after all, an essential element of state power. The gathering, storage, and use of information about subject populations is fundamental to the work of governance, whether for good (urban planning, provision of services, distribution of resources) or for ill (surveillance, gerrymandering, political repression). Much can be gleaned about the nature of a particular regime by examining its archival practices; a shift from military to civilian rule, for example, should necessarily include a shift in policies regulating public access to information. But the extent of that shift will always depend on the intersection of multiple factors: the depth of the regime's commitment to democracy and transparency; the existence of independent archival institutions with the capacity to resist politically motivated interference; robust legal frameworks to guard against such interference; the availability of funding, infrastructure, and trained archival personnel; the vigilance of international allies and observers; and, crucially, the degree of citizen mobilization around access. Fragility in one area imperils the whole endeavor.

The saga of the AHPN is not the first time that Guatemala's historical processes have unfolded at an outsized scale, its asymmetries of power uncommonly stark. And as in previous moments - such as its especially gory iteration of the Spanish invasion in the 16th century, the Central Intelligence Agency-assisted overthrow of democratically elected president Jacobo Arbenz, or the genocidal violence its security forces wrought upon civilians during the 1980s in the name of fighting communism - the specifics of the Guatemalan experience illuminate the broader phenomena at hand. Compared to the AHPN, other bodies of threatened records will tend to be less monumental, their physical condition less degraded, the backlash against their rescue less severe. But it is in the very extremity of its conditions, with the fact of its muzzling being only one twist in a tale that has consistently defied all expectations, that the AHPN makes manifest the dizzying stakes, and the electric archival politics, of historical knowledge production.

Shedding light on the tremendous violence of Guatemala's long internal armed conflict has proven a steeply uphill struggle. With the exception of Colombia, it was the region's most devastating Cold War era confrontation: as many as 200,000 Guatemalans were killed, 45,000 more 
were made to disappear without a trace, and the military state perpetrated acts of genocide against the indigenous Maya population as a core component of its counterinsurgency strategy. In 1996, the army and what remained of the Unidad Revolucionaria Nacional Guatemalteca (URNG) guerrilla forces signed peace accords. Among a set of measures designed to promote "reconciliation," if not accountability, the accords established a UN-sponsored truth commission called the Comisión para el Esclarecimiento Histórico (CEH), which was in theory entitled to access to any and all state documents it deemed necessary to carry out its investigation of human rights violations committed during the war. Because it was obvious that Guatemalan state forces had committed the vast majority of those violations, which included hundreds of scorched-earth massacres in civilian communities as well as the targeted assassinations of thousands who opposed military rule, government documents would have been a critical source of evidence. But, as CEH lead commissioner Christian Tomuschat later attested, the sitting government, closely allied with the military, stonewalled the commission, claiming that the relevant files had been stolen, lost, or destroyed (Tomuschat, 2001). The CEH was forced to base its study primarily on forensic evidence and oral testimony - allowing the military to dismiss the final report because it was not, as generals disingenuously proclaimed, substantiated by documentary evidence. That the report attributed $93 \%$ of the war's human rights violations to the state and state-led paramilitary groups might have had something to do with the strenuousness of their denials (CEH, 1999). When the commission issued its final 1999 report, a searing 12-volume excavation of a 500 -year-long history of racism and dispossession, the president refused to accept it at the ceremony, and the military high command stood up and turned their backs to the stage. It was a muted response compared to how the army had reacted to the Catholic Church's parallel truth-seeking effort, the Proyecto Interdiocesano Recuperación de la Memoria Histórica (REMHI) led by Bishop Juan José Gerardi Conedera, a year earlier. Two days after REMHI released its four-volume report, military intelligence operatives ambushed Gerardi outside his parish house and bludgeoned the beloved pastor to death with a ragged chunk of concrete (REMHI, 1998; Goldman, 2008).

It would be an understatement, therefore, to say that the horizon of possibility for historical reckoning and justice in the wake of the Peace Accords was narrow indeed. Those pushing to exhume mass graves, secure reparations for affected communities, or prosecute the architects of state violence were routinely targeted for retaliation. Gerardi's assassination was designed to send a message: forget the past, or else there will be consequences. The threat failed to derail the work of the country's most committed justice activists, but the realities of the stagnant postwar power structure largely thwarted their efforts, preserving impunity for army and police perpetrators and constituting a democracy in name only. 


\section{Kirsten Weld}

This made it all the more surprising when, in the summer of 2005, investigators from the human rights ombudsman's office (PDH) accidentally stumbled upon the archives of the now-defunct National Police while conducting an unrelated investigation in a little-traveled corner of a sprawling Guatemala City police base. Though it was the army that had executed the rural counterinsurgency and thus had killed the largest number of people, it was the National Police who had carried out much of the surgical violence in the capital city, often on the orders of military intelligence: the targeted killings and disappearances of student activists, labor leaders, progressive clergy, and university professors. As a result, finding the police's files - which the $\mathrm{CEH}$ had been blocked from consulting - had the potential to upend the postwar status quo, promising not only information that would help bring closure to bereaved families, but evidence of war crimes, written in the state's own hand.

The warehouse where the police files were found was an unbelievable scene, the dimensions of which were impossible to photograph and even harder to describe: tens of millions of documents rotting away in a halffinished warehouse, infested with rats and bats, resplendent with mold in many colors, dying a slow death of decay and neglect. It proved to be the largest discovery of secret state documents in the history of Latin America, roughly 75 million pages worth, and there was no precedent for how to deal with these papers, especially given the controversial nature of their contents. But in many respects, human rights advocates had been waiting for just such an opportunity, and they were ready to take the risk of trying to transform this archive of terror into an archive of justice. The rescue initiative that began immediately to take shape was at once intensely local - originally composed of staffers lent to the PDH by other human rights organizations and later supplemented by university students and others from the city's social justice community - and profoundly international, shaped by assistance from a coalition of allies based throughout the Americas and Europe. On the ground, the rescue team delved into the grimy work of digging through the heaps of paper and taking stock of what had been found; lacking any comparable precedent for how to deal with a discovery of this magnitude, these amateur archivists set about, somewhat improvisationally at first, figuring out how to clean, organize, interpret, and digitize the documents. Experts from abroad in human rights archiving would provide crucial assistance with strategic planning, as well as training in archival practice; the $\mathrm{PDH}$, taking advantage of its relationships with the international development agencies of governments like Switzerland and Spain, set about raising funds to support the work, with those funding streams outlasting the PDH's formal involvement with the archives. Though no one involved knew for how long they would be allowed to pursue it, the initiative's goal was clear from the outset: to restore the files and, in a sense, to repatriate them, to give them back to the Guatemalan people by organizing them, interpreting them, and making them available to the public. 
Despite much opposition faced along the way, from political interference to arson attempts, the AHPN, as it came to be known, came to stand as a landmark example of what could be accomplished in terms of citizen empowerment vis-à-vis archives - not just in Latin America, but worldwide. At its height, it counted on an annual operating budget of more than 2 million dollars and a staff of roughly 150 people. Gustavo Meoño, formerly part of the national directorate of the Ejercito Guerrillero de los Pobres (EGP), led the AHPN from 2005 on with a capacious and creative spirit. Interested parties from outside the project - documentary filmmakers, photographers, novelists, academic researchers, groups of local students, and more - would find themselves welcomed, security conditions permitting, and invited to produce their own interpretations of the rescue project unfolding before them (Doyle, 2007; Stelzner, 2009; Rey Rosa, 2009; Guberek and Hedstrom, 2017). By 2009, a public consultation service was open and running, allowing everyday citizens and human rights lawyers alike to conduct research. The AHPN pioneered collaborations with likeminded initiatives, such as the Forensic Anthropology Foundation of Guatemala (FAFG), which exhumes mass graves and uses DNA analysis to try and identify the remains, hoping to repatriate them to surviving family members; the FAFG and AHPN worked together to try and match some of the many unidentified corpses buried in Guatemala City's main cemetery with police records that might offer some clues as to these bodies' identities (Jones, 2016). The AHPN also took pains to share its resources, in particular its trained staff and high-volume scanners, to help digitize other collections of records at risk - important in a country which at the moment of the police files' discovery had fewer than ten trained archivists, and where the AHPN's access to foreign funding meant that it had access to far greater financial and technical resources than even the Archivo General de Centro América (AGCA), the country's national archives. It provided critical evidence in an array of human rights prosecutions, helping break the logjam of impunity that had hitherto protected the perpetrators of war crimes. And, most famously, the AHPN managed to digitize some 20 million pages of the files, backing them up on remote servers in the United States and Switzerland and making them freely available online by way of a collaboration with the University of Texas at Austin, with the hope that digitization would help guarantee continued access to the archives' information in the event of any future threat to the physical papers.

In short, then, the AHPN managed to considerably widen Guatemala's postwar horizon of possibility - although, of course, it did not do so alone. Rather, a constellation of actors and initiatives collectively co-produced the conjuncture that enabled the AHPN to flourish. The UN-backed Comisión Internacional Contra la Impunidad en Guatemala, or CICIG, set up shop in 2007, and for more than a decade it worked to root out corruption and the influence of so-called parallel powers in the country's government and judiciary, notably leading to the 2015 ouster and arrests of President Otto 


\section{Kirsten Weld}

Pérez Molina and Vice-President Roxana Baldetti for customs fraud (Open Society Justice Initiative, 2016). In 2010, the crusading reformer Claudia Paz y Paz took the helm of the Public Ministry as Attorney General, and in her four-year tenure she oversaw a brisk cascade of successful prosecutions of army and police officials for high-impact human rights crimes committed in the late 1970s and 1980s - including a historic trial of former dictator Efraín Ríos Montt for the crime of genocide. ${ }^{2}$ Two key offices more often than not occupied by antagonists of postwar justice, the Guatemalan presidency and the United States ambassadorship, were during this period held by sympathetic figures, Álvaro Colóm and Stephen McFarland. That the stars seemed to align during these brief years was no cosmic accident, but the fruit of many years of difficult and dangerous work by activists who had devoted their lives to the idea of a more humane Guatemala, and who had managed, briefly, to seize this propitious moment.

The AHPN and its sister initiatives faced hostility from their earliest days, but as the prosecutions of perpetrators gathered steam, the reaction intensified. As the Ríos Montt trial unfolded, Guatemala's Congress overwhelmingly passed a declaration stating that there had been no genocide, with its president stating, "what we as a Congress are saying is let's forget the past." A far-right organization called the Foundation Against Terrorism published blacklists of the justice activists involved in ongoing legal cases, and its supporters appropriated their adversaries' visual repertoires, parading through the streets bearing photos of family members they claimed had been killed by Communists. Organizations like AVEMILGUA, the powerful military veterans' association, took out paid advertisements in local newspapers threatening violence. For a time, despite these worrying signs and the project's ongoing legal and political precariousness, the AHPN continued its regular work, digitizing records, facilitating access for researchers, and assisting in legal cases.

But one prosecution, of five high-ranking army officials found responsible for the 1981 abduction, torture, and rape of Emma Guadalupe Molina Thiessen and the forced disappearance of her 14-year-old brother Marco Antonio, would prove, in Meoño's words, "la gota que rebasó el vaso" the final straw (Colombia 2020, 2018). And when it did, the favorable context that had insulated the AHPN from attacks during its first decade had dissipated.

In 2016, a political neophyte and comedian named Jimmy Morales, then best known for his blackface routines, was elected president of Guatemala, running on a conservative platform. Coalescing quickly around him were the power players and interests of a previous era: AVEMILGUA, the business elites, the oligarchy - the very sectors which had been targeted by the recent turn toward increased transparency, anticorruption campaigns, 
and postwar justice. Morales's victory emboldened long-standing enemies of CICIG, the AHPN, the Public Ministry under Thelma Aldana (Paz y Paz's successor), and the entire constellation of human rights and justice organizations at work in Guatemala. Those enemies would mobilize swiftly to enact what they referred to openly as a counterrevolution (Doyle and Oglesby, 2018).

Just as international circumstances had assisted the work of the AHPN in calmer times, so too would international circumstances fuel the fires of this counterrevolutionary effort, because, as it happened, Morales was not the only political neophyte elected to a presidency in the Americas that year. Donald Trump took office with narrow and self-serving priorities when it came to Latin America policy. First, he wanted allies in his push to move the foreign embassies in Israel from Tel Aviv to Jerusalem, a pet cause of U.S. evangelicals. Second, he wanted to roll back the steadily increasing uptick of children and families fleeing poverty, violence, and climate change in Central America, whom he called "invaders" (Peters, 2018). That Morales's aspirations were equally narrow and self-serving would form the basis for a realignment of the Guatemalan political landscape. Morales, under investigation by CICIG for having accepted illegal campaign contributions in the 2016 election, hoped to seek exile in the United States after his term in office ended, to avoid facing criminal charges for illicit self-dealing. Eager to please the Trump administration, he promptly moved Guatemala's embassy to Jerusalem and presided over the creation of a "safe third party agreement" which enabled the United States to deport asylum-seekers to Guatemala (Noack, 2018; Narea, 2019).

As this craven deal unfolded, arguments began to be heard in the Molina Thiessen case, which had been wending its way through the courts since 1997. The accused were all "untouchables" from Guatemala's military high command: Manuel Antonio Callejas Callejas, Francisco Luis Gordillo Martínez, Edilberto Letona Linares, Hugo Ramiro Zaldaña Rojas, and, importantly, Manuel Benedicto Lucas García, the ex-chief of the General Staff of the military. Letona Linares was acquitted, but the other four were convicted in May 2018 and collectively sentenced to more than 200 years in prison (Burt and Estrada, 2018). This was dangerous territory indeed. Benedicto Lucas García had friends in very high places: he and his wife had been major players in Morales's electoral campaign, and he was the brother of former dictator Romeo Lucas García (Gutiérrez Valdizán, 2016). And the AHPN had provided indispensable documentary evidence to the prosecution (Antonio, 2018).

After the conclusion of the Molina Thiessen case came the deluge. In August 2018, Meoño was summarily removed from his position as AHPN director, initiating a procedural coup against the Archive (Doyle, 2018). Meoño faced death threats and had to leave Guatemala; as of this writing, he remains in exile. The remaining employees were placed on temporary contracts, soon to be fired outright. Control of the AHPN was transferred 


\section{Kirsten Weld}

from the national archives to the Ministry of Culture and Sports, which was run by a Morales loyalist. In January 2019, the Morales government announced that it would terminate the mandate of CICIG; in March of that year, it issued an arrest warrant against Thelma Aldana, who had been planning to run for president but instead fled into exile; in May, interior minister Enrique Degenhart announced severe restrictions on public access to AHPN documents, and threatened legal action against the "foreign institutions" safeguarding digitized copies of the records; in July, Anna Carla Ericastilla, the chief archivist at the AGCA and a key figure in the AHPN leadership, was fired from her long-standing position at the national archives and spuriously accused of professional malfeasance; in September, CICIG was made to close its doors, its director barred from reentering the country.

In the past, such a flagrant campaign against such respected democratizing institutions would have been denounced in no uncertain terms by the U.S. Embassy and the State Department, but this time, the Trump administration said next to nothing, providing Morales with a carte blanche to dismantle the AHPN. In the words of one U.S. official, this reflected "an unwritten bargain" between the two countries: "They promise not to let brown people into the country, and we let them get away with everything else" (Lynch, 2019). And as Democratic congressional representative Norma Torres put it, "The message [Guatemalan authorities] are getting is we don't care what you do as long as you do everything in your power to prevent" foreigners from reaching the U.S. border (Lynch, 2019). Degenhart's announcement that the Morales government would end public and investigative access to the AHPN came on the same day that the Trump administration inaugurated its "safe third party agreement" with Guatemala, making the National Police archives a chess piece in a perverse stratagem to gut international asylum rights for refugee families throughout the Americas.

History shows, however, that the law is contested terrain: often bent by the powerful in defense of their own interests, of course, but nevertheless a site of real potential for those seeking justice. Midway through the Morales administration's war on the AHPN, a coalition of activists, led by the human rights ombudsman's office, filed a last-ditch legal appeal, or ámparo, denouncing the government's sabotage campaign and demanding the resurrection of the archival rescue operation. It sat on the Supreme Court's docket for nearly a year.

But on March 3, 2020, the justices issued a surprising ruling in favor of the activists. The Court not only ordered the relevant government ministries, Interior and Culture, to refrain from undermining the AHPN's physical and fiscal integrity, but also instructed them to reverse the damage of the preceding 18 months by restoring previous levels of staffing, support, and oversight, all per the international norms governing archival preservation 
and the defense of human rights. Finally, the ruling exhorted the country's Congress to approve draft legislation creating a new national archives law, which would more robustly protect initiatives like the AHPN from political interference in the future.

The ruling is welcome news - although its enforcement remains an open question. Morales's presidential term ended in January, but he was succeeded by another conservative, Alejandro Giammattei, linked to organized crime and military interests. And Giammattei has shown little inclination to reverse the course laid out by Morales. In February, for example, the Guatemalan Congress passed Decree 4-2020, which grants state authorities broad discretionary power to shut down civil society organizations, especially those which receive international funds or backing, whose activities are deemed to "disrupt public order." Decree 4-2020 was overturned by the Constitutional Court, though nothing prohibits Congress from reinitiating another legislative process designed to yield similar results - and the key message, that the government aims to rein in dissenting voices by any means possible, has already been communicated.

In short, this story is not over. What lessons might it hold for those working at the intersection of archival preservation and the defense of human rights?

First, if ever it was possible to sustain the premise that archival access and management were not fundamentally political, Guatemala conclusively demonstrates otherwise. State archives are never just papers. They are metaphors: for accountability, for the integrity of citizens' rights, for the depth of democratic transitions. But they are far more than metaphors, especially in a polarized post-counterinsurgency context like Guatemala's, where they represent a pair of dangers: that the intelligence information gathered in the past about human rights advocates could be weaponized against them a second time as they continue to seek justice, or, conversely, that the evidence of state responsibility for war crimes they contain could be used by those same human rights advocates to threaten the material interests of powerful sectors. It is a lot to expect of projects like the AHPN that they be able to navigate between Scylla and Charybdis without running aground.

Second, international partnerships can decisively boost the viability of efforts to save threatened archives - several statements by international allies were cited in the Supreme Court's March ruling - but they are not a panacea. On the one hand, without minimizing the labor and agency of the Guatemalans involved, it is difficult to imagine how the AHPN could have accomplished everything it did without the funding, training, and solidarity it received from abroad, whether from key individuals or from foreign states. Yet, on the other hand, international allies have little recourse if the national government is committed to starving or shutting down an archival rescue project, especially if that government is little interested in preserving its legitimacy. And in the case of Guatemala, the United States, which has historically wielded undue influence in the country, enabled the Morales 


\section{Kirsten Weld}

government's systematic onslaught against human rights and anticorruption efforts in exchange for the two-step quid pro quo of the Israel embassy move and cooperation in keeping migrants from seeking U.S. asylum. For as long as Trump remained in office, Guatemala's authoritarians - and the region's knew that they could probably get away, quite literally, with murder.

And, finally, the task of destabilizing official narratives about history and building bottom-up movements for accountability, representation, and justice is grueling and challenging. It fails far more often than it succeeds. And even when it does succeed - especially when it does - that success must be constantly defended, for it will be constantly threatened by those whose comfortable status quo it challenges. Politics is dialectical, not teleological. Human affairs do not inexorably improve, or become more just, in a linear fashion; democratic gains can be easily reversed. Guatemala's veteran activists, therefore, know that they must always keep playing the long game. As one AHPN worker reminded me (Weld, 2014), "Social victories are the fruit of the people's struggle, always. Nothing is easy, and it all represents a lot of work, no?"

\section{Notes}

1 Kirsten Weld's case study is written for this book but Routledge has granted permission for it to be published as an article in the Boston Review (9 July 2020).

2 These included the convictions of former National Police detective chief Pedro García Arredondo and former National Police director Héctor Bol de la Cruz in addition to ex-dictator Efraín Ríos Montt. On the Ríos Montt case, see Coronado, 2018.

\section{Bibliography}

Antonio, Simón. 2018, "La conspiración y persecución del estado contra la familia Molina Theissen," Prensa Comunitaria, 10 May. Available at www.prensacomu nitaria.org/la-conspiracion-y-persecucion-del-estado-contra-la-familia-molinatheissen/.

Burt, Jo-Marie, and Paulo, Estrada. 2018, "Four Retired Senior Military Officers Found Guilty in Molina Theissen Case," International Justice Monitor, 23 May. Available at www.ijmonitor.org/2018/05/four-retired-senior-military-officers-found-guiltyin-molina-theissen-case/.

Colombia 2020. 2018, "La condena de un militar motivó la salida del director del Archivo de Guatemala," El Espectador, 23 October. Available at www.elespec tador.com/colombia2020/justicia/verdad/la-condena-de-un-militar-motivo-lasalida-del-director-del-archivo-de-guatemala-articulo-857279.

Comisión para el Esclarecimiento Histórico (CEH). 1999, Guatemala: Memoria del silencio, 12 vols. Guatemala City: United Nations Office of Project Services.

Coronado, Elsa. 2018, "Ríos Montt: La muerte y la impunidad llegan juntas," Plaza Pública, 2 April. Available at www.plazapublica.com.gt/content/riosmontt-la-muerte-y-la-impunidad-llegan-juntas. 
Doyle, Kate. 2007. "The Atrocity Files: Deciphering the Archives of Guatemala's Dirty War," Harper's Magazine, pp. 34-40.

_ 2018, "Guatemala Police Archive Under Threat.” National Security Archive, 13 August. Available at https://nsarchive.gwu.edu/news/guatemala/2018-08-13/ guatemala-police-archive-under-threat.

Doyle, Kate, and Elizabeth, Oglesby. 2018, "Why Guatemala's Anti-Corruption Commission Faces a New Wave of Efforts to Derail It," World Politics Review, 23 May. Available at www.worldpoliticsreview.com/articles/24775/why-guatemalas-anti-corruption-commission-faces-a-new-wave-of-efforts-to-derail-it.

Goldman, Francisco. 2008, The Art of Political Murder: Who Killed the Bishop? New York: Grove Press.

Guberek, Tamy, and Hedstrom, Margaret. 2017, “On or Off the Record? Detecting Patterns of Silence About Death in Guatemala's National Police Archive," Archival Science, vol. 17, pp. 27-54.

Gutiérrez Valdizán, Alejandra. 2016, “El general volvió de su apacible retiro,” Plaza Pública. Available at www.plazapublica.com.gt/content/el-general-volvio-de-suapacible-retiro.

Jones, Maggie. 2016, “The Secrets in Guatemala's Bones,” The New York Times Magazine, 30 June. Available at www.nytimes.com/2016/07/03/magazine/thesecrets-in-guatemalas-bones.html.

Lynch, Colum. 2019, “Guatemala Declares War on History,” Foreign Policy, 30 July. Available at https://foreignpolicy.com/2019/07/30/guatemala-declares-waron-history-dirty-war-archives-jimmy-morales/.

Narea, Nicole. 2019, “Trump's Agreements in Central America Are Dismantling the Asylum System as We Know It," Vox, 20 November. Available at www. vox.com/2019/9/26/20870768/trump-agreement-honduras-guatemala-elsalvador-explained.

Noack, Rick. 2018, "Why Some Latin American Countries Are Rushing to Open Jerusalem Embassies, Too," The Washington Post, 16 May.

Open Society Justice Initiative. 2016, Against the Odds: CICIG in Guatemala. Available at www.refworld.org/docid/5799f4814.html.

Peters, Jeremy W. 2018, "How Trump-Fed Conspiracy Theories About Migrant Caravan Intersect with Deadly Hatred," The New York Times, 29 October.

Proyecto Interdiocesano de Recuperación de la Memoria Histórica (REMHI). 1998, Guatemala: Nunca más! Guatemala City: Oficina de Derechos Humanos del Arzobispado de Guatemala.

Rey Rosa, Rodrigo. 2009, El material humano. Barcelona: Editorial Anagrama.

Stelzner, Uli, dir. 2009, La Isla: Archives of a Tragedy. Iska Cine. Available at https:// www.imdb.com/title/tt1590791/.

Tomuschat, Christian. 2001. "Clarification Commission in Guatemala," Human Rights Quarterly, vol. 23, no. 3, pp. 233-258.

Weld, Kirsten. 2014, Paper Cadavers: The Archives of Dictatorship in Guatemala. Durham, NC: Duke University Press. 